\title{
Air-Based Photoelectrochemical Cell Capturing Water Molecules from Ambient Air for Hydrogen Production
}

Received ooth January 2012, Accepted ooth January 2012 DOI: $10.1039 /$ xoxxooooox www.rsc.org/

\author{
J. Rongé, ${ }^{a}$ S. Deng, ${ }^{b}$ S. Pulinthanathu Sree, ${ }^{a}$ T. Bosserez,${ }^{a}$ S. W. Verbruggen,${ }^{a}$ N. \\ Kumar Singh, ${ }^{a}$ J. Dendooven, ${ }^{b}$ M. B. J. Roeffaers, ${ }^{a}$ F. Taulelle,${ }^{a, c}$ M. De Volder, ${ }^{d}$ C. \\ Detavernier, ${ }^{b}$ J. A. Martens ${ }^{a, *}$
}

A system is demonstrated that autonomously produces hydrogen gas using sunlight and outside air as the only inputs. Oxygen and hydrogen formation reactions occur on either side of a monolithic "solar membrane" inserted in a two-compartment photoelectrochemical cell. A surface film of Nafion ${ }^{\circledR}$ serves as solid electrolyte. This proof of concept invites for further development of air-based cells.

The prospect of solar hydrogen as a sustainable energy source spurs steady progress toward efficient materials for water splitting ${ }^{1-6}$. While current systems run on liquid water, the idea of feeding water contained in ambient air to a solar water splitting device is appealing. The imaginative concept has been proposed recently by Dionigi et ll $^{7}$ and Xiang et ll. $^{8}$. These authors argued that vapor phase water photoelectrolysis avoids deleterious effects associated with bubble formation in aqueous medium. We add that operation in ambient air reduces maintenance costs, as the possibility of corrosion and poisoning is reduced. In addition, liquid pumping systems are not needed since natural convection of air can feed the water vapor, and the risk of freezing is minimized. ${ }^{9}$ Finally, capturing water from the air implies that virtually no liquid water is needed for operation, making it a water-neutral process. Here, we report for the first time experimental demonstration of a solar-driven unbiased photoelectrochemical (PEC) cell producing hydrogen gas from water vapor present in the air.

Hydrogen formation from gaseous water molecules on semiconductor powders was a subject of fundamental studies in the early 1980s. ${ }^{10-15}$ Schrauzer and Guth reported hydrogen formation from water vapor on an illuminated titanium dioxide $\left(\mathrm{TiO}_{2}\right)$ surface under inert atmosphere. ${ }^{10}$ Their results were disputed, ${ }^{11}$ but later confirmed using isotope tracing. ${ }^{12}$ Wagner and Somorjai coated strontium titanate semiconductor with deliquescent sodium hydroxide to absorb the water vapor. ${ }^{13}$ Sato and White performed gas phase experiments using $\mathrm{TiO}_{2}$ powder coated with platinum cocatalyst, but back reaction limited the hydrogen yield. ${ }^{14}$ More recently, Dionigi et al. showed that the photocatalytic water splitting reaction is critically dependent on the presence of a condensed water film on the semiconductor surface for proton conductivity from oxidation to reduction sites. ${ }^{7}$ Providing water through the air aimed at in the present study entails the additional challenge of exposing the photoanode to an oxygen containing atmosphere. Oxygen molecules are mediators for recombination, can cause back reaction and deteriorate photoefficiency. ${ }^{16}$ Concepts to alleviate the problems caused by relatively low concentrations of oxygen molecules from the water splitting reaction have been proposed, such as application of a chromia shell, ${ }^{17}$ and surface carbonate species on $\mathrm{TiO}_{2},{ }^{18}$ but the high oxygen concentration of air has not yet been dealt with.

Oxygen-related side reactions are initiated by electron capture by molecular oxygen. To minimize the detrimental impact of oxygen, electrons should be rapidly extracted from the semiconductor to a conducting back contact. Carbon nanotube (CNT) films have been demonstrated as transparent or textured conducting back contacts in solar devices. ${ }^{19,20}$ Metal oxide - CNT hybrids show improved performance for photocatalytic degradation of pollutants and hydrogen production. ${ }^{21,22}$ This is explained in terms of efficient electron extraction from the semiconductor, thus preventing charge carrier recombination. Most hybrid CNT materials are synthesized by conventional sol-gel or hydrothermal methods, ${ }^{21}$ which yield thick, inhomogeneous films with many defects. Eder suggested that a uniform, continuous coating of metal oxide on CNT would greatly enhance performance. ${ }^{21}$ We prepared hierarchical electrodes consisting of carbon fibers coated with multi-walled carbon nanotube (MWCNT) networks serving as a 'highway' for electrons (Figure 1A,B). The MWCNTs were coated with a continuous film of $\mathrm{TiO}_{2}$ semiconductor. The $\mathrm{TiO}_{2}$ thin film's crystal quality and electrical contact with the MWCNTs are of key importance. The presence of multiple grain boundaries is detrimental to charge transport because photogenerated carriers are scattered or trapped leading to recombination. ${ }^{23}$ Atomic layer deposition (ALD) is the method of choice to prepare high quality uniform $\mathrm{TiO}_{2}$ thin films. ${ }^{24}$ ALD is characterized by the alternate exposure of the surface to a chemical precursor with self-limiting surface reactions followed by 
hydrolysis and oxidation, producing films with accurate thickness control, excellent conformality, and uniformity over large areas. Through ALD a uniform ultrathin $\mathrm{TiO}_{2}$ shell was deposited on MWCNT core (Figure 1C). The MWCNT forest provides large surface area while still allowing light penetration and gas evacuation. The as-deposited about $10 \mathrm{~nm}$ thick amorphous $\mathrm{TiO}_{2}$ coating on the MWCNTs was crystallized to anatase by heating at $550{ }^{\circ} \mathrm{C}$ for $3 \mathrm{~h}$ under air (Figure S1-S2). Raman spectroscopy (Figure 2) and highresolution scanning electron microscopy (HR-SEM) (Figure S3) revealed that MWCNTs were preserved inside the anatase $\mathrm{TiO}_{2}$ nanotubes. This is remarkable, since thermogravimetric analysis (TGA) indicated that uncoated MWCNTs undergo oxidation above $500{ }^{\circ} \mathrm{C}$ (Figure 2). Previous studies have shown that the deposition of metal oxides on CNTs can significantly affect their stability. ${ }^{25}$ In the case of most metal oxides including $\mathrm{TiO}_{2}, \mathrm{CNT}$ thermal stability is reduced by more than $100{ }^{\circ} \mathrm{C}$. This has been explained by a Mars - van Krevelen mechanism: first, carbon atoms from the CNT react with lattice oxygen from the metal oxide. Subsequently, the created oxygen vacancy diffuses to the gas/solid interface and is healed by gaseous oxygen. ${ }^{25}$ However, in our case TGA analysis showed that MWCNT thermal stability is enhanced by over $200{ }^{\circ} \mathrm{C}$ (Figure 2). This is the first time a CNT shows enhanced stability after deposition of $\mathrm{TiO}_{2}$. Most of the reported $\mathrm{TiO}_{2} / \mathrm{CNT}$ materials show cracks and other defects. ${ }^{25-27}$ In our case, we believe the pinhole-free coating prevents oxygen vacancies from reaching the gas/solid interface so oxidation is avoided.

For the cathode a well-dispersed Pt nanophase was deposited on the MWCNTs using ALD (Figure 1D). The deposited platinum was clustered in $\sim 5 \mathrm{~nm}$ particles uniformly spread over the MWCNT surface. The small size and monodispersity of the deposited $\mathrm{Pt}$ nanoparticles ensured high availability of catalytic surface for hydrogen production, despite a low Pt loading of $13 \mu \mathrm{g} \mathrm{cm}^{-2}$. Pt islands on CNTs have previously been demonstrated for fuel cell applications. ${ }^{28-30}$ In those examples, CNTs were functionalized by acid treatment, followed by ALD using $\mathrm{O}_{2}$ as the oxidant. Here a process with $\mathrm{O}_{3}$ as the oxidant was used, ${ }^{31}$ and pretreatment of CNTs was not necessary.

The design of our monolithic solar membrane with Nafion ${ }^{\circledR}$ membrane, carbon fiber support and the $\mathrm{TiO}_{2} / \mathrm{MWCNT}$ and $\mathrm{Pt} / \mathrm{MWCNT}$ electrodes is presented in Figure 1. Proton conducting membranes such as Nafion ${ }^{\circledR}$ are convenient for separating the two electrode compartments and to collect the produced hydrogen gas separately. ${ }^{8,32}$ By fixing the electrodes directly on either side of such membrane, anode to cathode proton transport distance can be made very short and efficient. ${ }^{33-35}$ Proton conductivity through the solar membrane was further enhanced by covering the MWCNT/carbon fiber electrodes with a surface layer of Nafion ${ }^{\circledR}$ (Figure S4). This film eliminates the need of a liquid electrolyte. Optimal design of the film is critical for device performance, since ionic resistance losses in the catalyst layer can be higher than losses in the membrane itself. $^{36}$ Thin Nafion ${ }^{\circledR}$ films $(<500 \mathrm{~nm})$ have reduced proton conductivity, especially at low relative humidity (RH). ${ }^{37,38}$ On the other hand, modeling of vapor phase PEC cells has shown that film thickness should not surpass $2.9 \mu \mathrm{m}$ so as not to impede product gas evacuation. ${ }^{8}$ By drop casting $5 \mathrm{wt} \% \mathrm{Nafion}^{\circledR}$ solution and evacuating excess material, we obtained a film thickness of $\sim 2.5 \mu \mathrm{m}$.
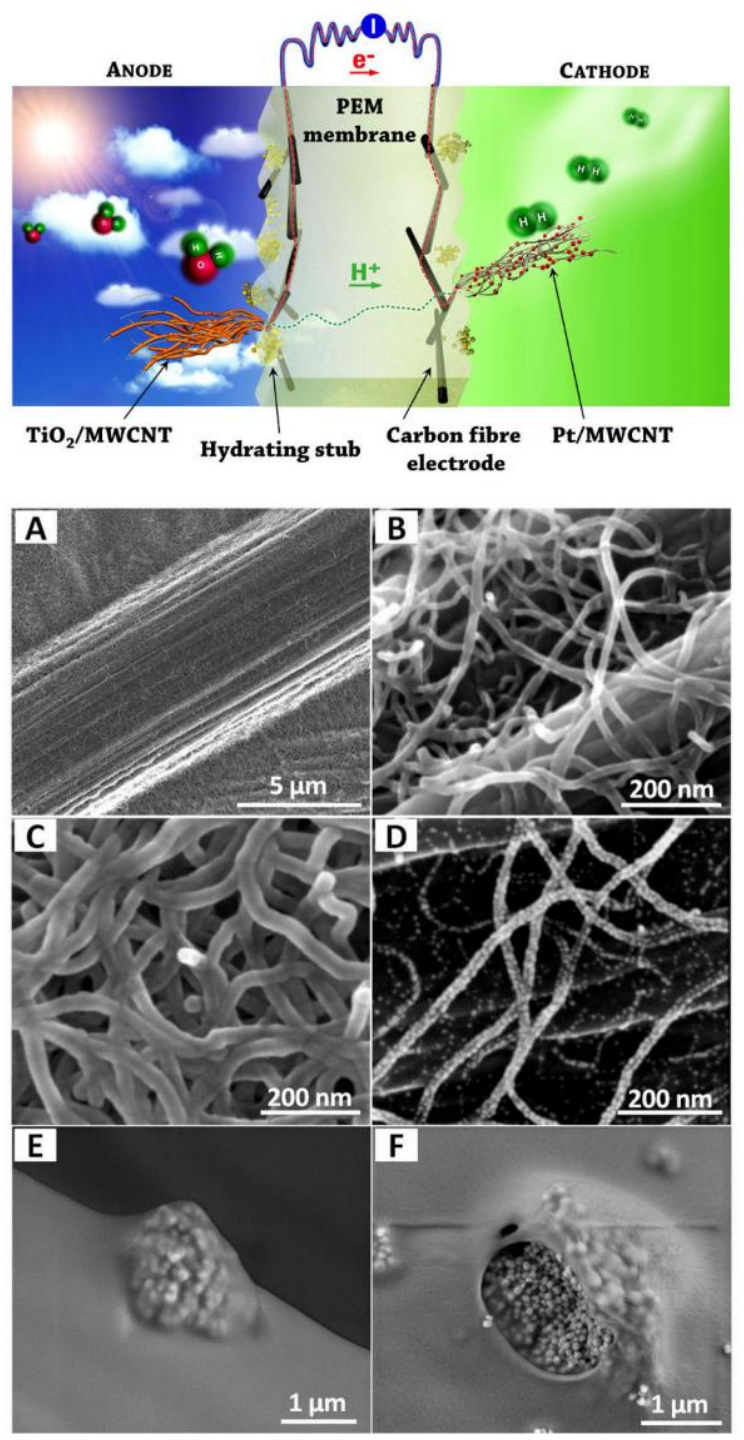

Figure 1. Top: Conceptual scheme of the solar membrane with a photoanode made from multi-walled carbon nanotubes grafted on carbon fiber electrode with conformal anatase $\mathrm{TiO}_{2}$ thin film coating $\left(\mathrm{TiO}_{2} / \mathrm{MWCNT}\right), \mathrm{Nafion}^{\circledR}$ proton exchange membrane (PEM), and platinum-decorated MWCNTs (Pt/MWCNT) at the cathode producing hydrogen gas using the electrons and protons from the water oxidation. Electrode surfaces are provided with water adsorbing zeolite stubs. Bottom: HR-SEM images of individual parts: $(A, B)$ carbon fiber with grafted MWCNTs, better visible at higher magnification; (C) conformal thin film $\mathrm{TiO}_{2}$ coating on

MWCNTs at the anode; (D) cathode MWCNTs with Pt nanoparticles; (E,F) hydrating zeolite stubs.

Nafion ${ }^{\circledR}$ requires a high degree of hydration for proton conductivity, which can be problematic in ambient air at limited RH. Zeolites are known for their excellent water adsorbing properties and have previously been employed in high-temperature fuel cell applications. ${ }^{39}$ A zeolite devoid of alkali and alkaline earth metal cations was selected to avoid cation exchange with Nafion ${ }^{(}$. Silicalite nanopowder ${ }^{40}$ was embedded in the superficial Nafion ${ }^{\circledR}$ layers of the solar membrane. The zeolite was found concentrated as surface stubs (Figure 1E,F). The effectiveness of the zeolite addition was demonstrated by a temperature-controlled water sorption 
experiment (Figure S5). Electrodes covered with $\mathrm{Nafion}^{\circledR}$ with or without zeolite were dried at $120{ }^{\circ} \mathrm{C}$ under nitrogen flow. Subsequent exposure to humidified nitrogen gas (absolute humidity $\left.24 \mathrm{~g} \mathrm{~m}^{-3}\right)$ at $120{ }^{\circ} \mathrm{C}(\mathrm{RH}=1.5 \%)$ gave rise to fast water uptake. Upon cooling, the water content of the electrode further increased. At $50{ }^{\circ} \mathrm{C}(\mathrm{RH}=25 \%)$, the presence of $2 \mathrm{wt} \%$ zeolite leads to $120 \%$ higher water uptake. Although at this stage the mechanism of the water transfer from zeolite to Nafion ${ }^{\circledR}$ is unknown, the zeolite guarantees wetting of the electrodes under operation at reduced humidity.
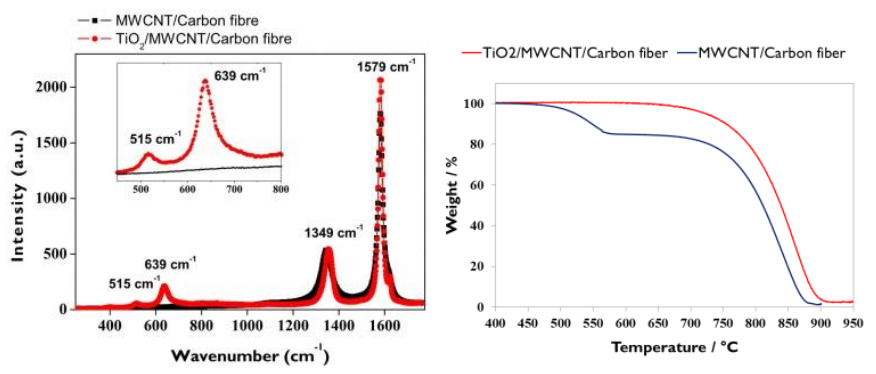

Figure 2. Left: Characteristic Raman signals of MWCNTs (1349 $\mathrm{cm}^{-1}$ and $1579 \mathrm{~cm}^{-1}$ ) before $\mathrm{TiO}_{2}$ ALD deposition (black trace) and after $\mathrm{TiO}_{2}$ deposition and crystallization at $550{ }^{\circ} \mathrm{C}$ (red trace). Inset shows close-up of characteristic anatase $\mathrm{TiO}_{2}$ signals $\left(515 \mathrm{~cm}^{-1}\right.$ and $639 \mathrm{~cm}^{-1}$ ) only present in the sample after ALD. Right: TGA under oxygen atmosphere of anode consisting of MWCNTs grafted on carbon fiber electrode with and without $\mathrm{TiO}_{2}$. Without $\mathrm{TiO}_{2}$ coating, the onset of nanotube oxidation is at $\sim 450{ }^{\circ} \mathrm{C}$. $\mathrm{TiO}_{2}$ coating shifts the stability to $\sim 650{ }^{\circ} \mathrm{C}$. The large weight loss at high temperatures is due to oxidation of the carbon fiber substrate.

The solar membrane was mounted in a two-compartment cell for performance evaluation. The anode compartment was left open to humidified outside air. The cathode compartment was filled with dry nitrogen gas and sealed. A relatively stable photocurrent was obtained under UV illumination (Figure 3A). Consistent performance was achieved for several illumination periods. Hydrogen production was quantified for each period (Figure 3B). The Faradaic efficiency, defined as the percentage of anode-tocathode transferred electrons giving rise to hydrogen formation, was close to $100 \%$ in each of the measurements. Replacing the $\mathrm{TiO}_{2} /$ MWCNT anode with an anode where $\mathrm{TiO}_{2}$ nanoparticles are electrophoretically deposited revealed a detrimental effect of atmospheric oxygen on performance (Figure S6). In presence of air the photocurrent was over two times lower and photocurrent decay more pronounced. The discontinuous nature of clustered $\sim 20 \mathrm{~nm}$ $\mathrm{TiO}_{2}$ particles with multiple grain boundaries in that case was thought responsible for photoelectron quenching by molecular oxygen. ${ }^{35}$

To confirm the occurrence of water splitting, $\mathrm{N}_{2}$ gas flow was humidified with $\mathrm{H}_{2}{ }^{18} \mathrm{O}$ and fed to the photoanode compartment. ${ }^{36} \mathrm{O}_{2}$ formation was detected under illumination, confirming occurrence of water oxidation (Figure S7). Formation of ${ }^{34} \mathrm{O}_{2}$ was detected as well, since the membrane contained residual $\mathrm{H}_{2}{ }^{16} \mathrm{O} .{ }^{32} \mathrm{O}_{2}$ formation out of $\mathrm{H}_{2}{ }^{16} \mathrm{O}$ was likely to occur, but could not be quantified due to background signal. The Faradaic efficiency for ${ }^{36} \mathrm{O}_{2}$ was $53 \%$, and adding the contribution of ${ }^{34} \mathrm{O}_{2}$, it was around $85 \%$. Including an estimated value for the ${ }^{32} \mathrm{O}_{2}$ contribution, a total Faradaic efficiency for $\mathrm{O}_{2}$ of $c a$. $104 \%$ is obtained. The close to $100 \%$ Faradaic efficiency for both oxygen and hydrogen confirms the photoelectrochemical nature of overall water splitting in our PEC cell.

The stability of the performance was investigated by leaving the anode compartment open to ambient air (60\% relative humidity at 25 ${ }^{\circ} \mathrm{C}$ ) and illuminating with simulated sunlight for $24 \mathrm{~h}$ (Figure 3C,D). Prior to the experiment, the cathode compartment was flushed with dry nitrogen gas and sealed. The photocurrent gradually increased

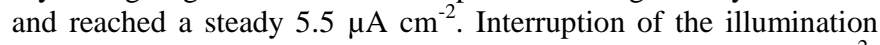
caused the current to return to very low values $\left(<50 \mathrm{nA} \mathrm{cm}^{-2}\right)$ confirming the photoelectrochemical nature of the process.

We placed the cell on the roof of our laboratory on a sunny day as a proof-of-concept for outdoor hydrogen production with realistic atmosphere and light conditions (Figure 3E,F). The cell was manually oriented towards the sun under a tilt angle of $30^{\circ}$. It was left outside for one hour periods, and taken back to the lab for analysis of the hydrogen content of the cathode compartment. That day, outside temperature rose from 26 to $31{ }^{\circ} \mathrm{C}$ during the measurements and relative humidity dropped from $55 \%$ at $8 \mathrm{~h}$ to $28 \%$ at $15 \mathrm{~h}$. The first two hours, hydrogen production was about 85 $\mathrm{nmol} \mathrm{h} \mathrm{cm}^{-2}$. Just after solar noon it peaked at $148 \mathrm{nmol} \mathrm{h}^{-1} \mathrm{~cm}^{-2}$. Later, hydrogen production dropped to $62 \mathrm{nmol} \mathrm{h}^{-1} \mathrm{~cm}^{-2}$. This $\mathrm{H}_{2}$ production rate is similar to that of the closest state-of-the-art laboratory experiment, in which hydrogen and oxygen were coproduced in water-saturated helium carrier gas sent over $\mathrm{GaN}: \mathrm{ZnO}$ semiconductor powder with $\mathrm{Rh}_{2-\mathrm{y}} \mathrm{Cr}_{\mathrm{y}} \mathrm{O}_{3}$ co-catalyst. ${ }^{7}$
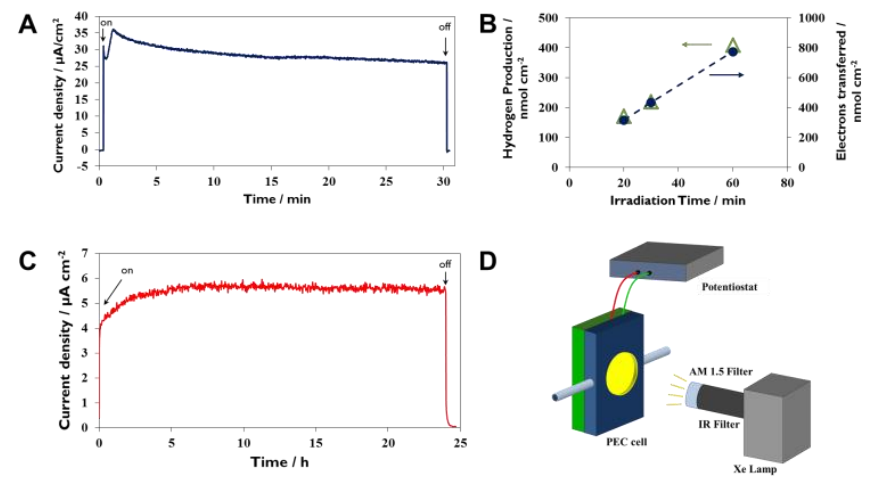

E

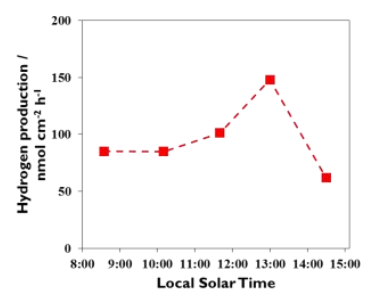

$\mathbf{F}$

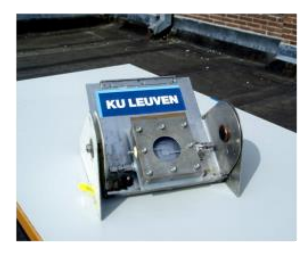

Figure 3. (A,B) Photocurrent profile and hydrogen production obtained when the PEC cell is illuminated with UV light at $50 \mathrm{~mW}$ $\mathrm{cm}^{-2}$. The cathode was filled with dry nitrogen and then sealed for different time periods, followed by analysis of the hydrogen content. The anode was pretreated with a flow of humidified outside air and left open to outside air during illumination. Arrows indicate when the light was switched on or off. (C,D) Laboratory experiment of

water splitting with the solar membrane in ambient air using simulated solar light (Air Mass 1.5; $100 \mathrm{~mW} \mathrm{~cm}^{-2}$ ). Photocurrent was registered during 24 hours of continuous illumination. (E,F)

Hydrogen production from outside air and natural sunlight at different times of the day in the PEC cell installed on a table on the roof of the laboratory building. 
Our solar membrane is robust and reliably produces hydrogen gas without the need for pre-conditioning. The same assembly was used for over twenty experiments in a two-month period. It was stored between experiments without special measures. The cell could be assembled and disassembled without any deterioration of performance, both under well-controlled laboratory conditions and outdoors. The stability enhancement of MWCNTs coated with a protective $\mathrm{TiO}_{2}$ layer was evidenced by HR-SEM investigation of a photoanode after prolonged use (Figure S8). While the stable photocurrents confirmed the robustness of the MWCNTs, the carbon fiber substrate underwent some photocatalytic oxidation (Figure S9) and in future designs, a more inert substrate is desirable.

Over the years the performance of liquid phase cells has been improved significantly by implementing e.g. semiconductor junctions, and air-based systems could rapidly improve by adopting similar concepts. The versatility of our solar membrane is an advantage, as new materials may be incorporated without altering the two-compartment concept. Alternative semiconductor materials such as e.g. $\mathrm{BiVO}_{4}{ }^{1}$ or $\mathrm{Fe}_{2} \mathrm{O}_{3},{ }^{41}$ in a semiconductor $\mathrm{Z}$ scheme with a suitable photocathode material, ${ }^{42,43}$ will enhance visible light absorption and limit photodegradation of carbon fiber substrate.

\section{Conclusions}

In PEC cell development, the use of a proton exchange membrane currently is the only successful approach to minimize product crossover. $^{44,45}$ In liquid phase membrane-based devices the water purity is critical. The risk of contaminating electrodes and membrane by solutes is lower when using air instead of a liquid water supply. The use of air as the feed of future PEC installations could be a way to reduce complexity and cost. Frost protection is not needed. Water supply management can be very simple, since air supply could be achieved by natural convection. ${ }^{46}$ A hypothetical PEC cell with 5\% STH efficiency will consume water at a rate of $c a .10 \mathrm{~g} \mathrm{~m}^{-2} \mathrm{~h}^{-1}$ to generate $c a .1 \mathrm{~g} \mathrm{~m}^{-2} \mathrm{~h}^{-1}$ of hydrogen, or an energy equivalent of 120 $\mathrm{kJ} \mathrm{m}^{-2} \mathrm{~h}^{-1}$. The minimum needed air volume at $20{ }^{\circ} \mathrm{C}, 1013 \mathrm{hPa}$ and $60 \% \mathrm{RH}$ then is $\sim 1 \mathrm{~m}^{3} \mathrm{~h}^{-1} \mathrm{~m}^{-2}$. Even in the Sahel desert, at an average RH of about $20 \%$ and temperatures of $29{ }^{\circ} \mathrm{C},{ }^{47}$ one cubic meter of air contains $6 \mathrm{~g}$ water. Spurgeon and Lewis showed that, at $100 \% \mathrm{RH}\left(20^{\circ} \mathrm{C}\right)$, a water electrolyzer operating in the vapor phase can sustain an electrolysis current of $>20 \mathrm{~mA} \mathrm{~cm}$, which would correspond with $\sim 25 \%$ STH efficiency in a PEC cell. ${ }^{48}$ This estimation suggests that water supply is no rate-limiting factor in vapor phase cells, provided they contain hygroscopic coatings for concentrating water from ambient air on the photoactive surface. ${ }^{46}$ All these advantages of air-based PEC cells are arguments for gas phase PEC cell development.

Obviously, alternatives for renewable hydrogen production already exist, and the combination of photovoltaics and water electrolysis is well established. Hydrogen production via photovoltaic-driven electrolysis already has low water use. ${ }^{49}$ Due to its simplicity and zero liquid water consumption, air-based assemblies may become an attractive alternative. Besides carbon-neutral, renewable energy production ideally should also be water-neutral, to avoid jeopardizing local fresh water supplies. Water-neutral, carbonneutral production of solar fuel uniquely decouples climate change, water scarcity and energy production and could provide solutions for the water-energy-food nexus.

\section{Acknowledgements}

J.R., S.W.V. and M.D.V. acknowledge the Research Foundation Flanders (FWO). C.D. acknowledges funding from the European Research Council (FP7/239865) and BOF-UGent (GOA 01G01513). J.A.M. acknowledges the Flemish government for long-term structural funding (Methusalem) and the Belgian government (IAPPAI Interuniversity Networking). N.K.S. and M.B.J.R. acknowledge financial support from the European Research Council (ERC Starting Grant 307523 to M.B.J.R.). The authors thank Dorien Nijs for experimental assistance and Binoy V. Mohandas for the graphical illustration.

\section{Notes and references}

${ }^{a}$ Centre for Surface Chemistry and Catalysis, KU Leuven.

Kasteelpark Arenberg 23 box 2461, 3001 Leuven, Belgium.

E-mail: Johan.Martens@biw.kuleuven.be

${ }^{b}$ Department of Solid State Sciences, UGent.

Krijgslaan 281, 9000 Gent, Belgium.

${ }^{c}$ Tectospin, Institut Lavoisier, Université de Versailles.

Avenue des Etats Unis 45, 78035 Versailles, France.

${ }^{d}$ Department of Mechanical Engineering, KU Leuven.

Celestijnenlaan 300A, 3001 Leuven, Belgium.

Electronic Supplementary Information (ESI) available: Materials and methods, additional HR-SEM, XRD, Tauc plot, water sorption and MS characterization. See DOI: 10.1039/c000000x/

1. F. Abdi, L. Han, A. Smets, M. Zeman, B. Dam, and R. van de Krol, Nat. Commun., 2013, 4, 2195.

2. S. Y. Reece, J. A. Hamel, K. Sung, T. D. Jarvi, A. J. Esswein, J. J. H. Pijpers, and D. G. Nocera, Science, 2011, 334, 645-648.

3. J. Brillet, J. Yum, M. Cornuz, T. Hisatomi, R. Solarska, J. Augustynski, M. Graetzel, and K. Sivula, Nat. Photonics, 2012, 6, 824-828.

4. O. Khaselev and J. Turner, Science, 1998, 280, 425-427.

5. S. Licht, B. Wang, S. Mukerji, T. Soga, M. Umeno, and H. Tributsch, Int. J. Hydrogen Energy, 2001, 26, 653-659.

6. R. E. Rocheleau, E. L. Miller, and A. Misra, Energy \& Fuels, 1998, 12, 3-10.

7. F. Dionigi, P. C. K. Vesborg, T. Pedersen, O. Hansen, S. Dahl, A. Xiong, K. Maeda, K. Domen, and I. Chorkendorff, Energy Environ. Sci., 2011, 4, 2937-2942.

8. C. Xiang, Y. Chen, and N. S. N. Lewis, Energy Environ. Sci., 2013, 6, 3713-3721.

9. E. Chandross, Science, 2014, 344, 469-470.

10. G. Schrauzer and T. Guth, J. Am. Chem. Soc., 1977, 99, 71897193.

11. H. Van Damme and W. Hall, J. Am. Chem. Soc., 1979, 101, $4373-$ 4374.

12. T. Kawai and T. Sakata, Chem. Phys. Lett., 1980, 72, 87-89.

13. F. Wagner and G. Somorjai, J. Am. Chem. Soc., 1980, 102, 54945502 .

14. S. Sato and J. White, J. Catal., 1981, 69, 128-139.

15. K. Domen, S. Naito, and M. Soma, J. Chem. Soc. Faraday Trans., 1980, 543-544.

16. A. Hagfeldt, H. Lindström, S. Södergren, and S.-E. Lindquist, $J$. Electroanal. Chem., 1995, 381, 39-46.

17. K. Maeda, K. Teramura, D. Lu, N. Saito, Y. Inoue, and K. Domen, Angew. Chemie, 2006, 118, 7970-7973.

18. K. Sayama and H. Arakawa, J. Chem. Soc. Faraday. Trans., 1997, 93, 1647-1654.

19. A. Du Pasquier, H. E. Unalan, A. Kanwal, S. Miller, and M. Chhowalla, Appl. Phys. Lett., 2005, 87, 203511.

$20 . \quad$ C. L. Pint, K. Takei, R. Kapadia, M. Zheng, A. C. Ford, J. Zhang, A. Jamshidi, R. Bardhan, J. J. Urban, M. Wu, J. W. Ager, M. M. Oye, and A. Javey, Adv. Energy Mater., 2011, 1, 1040-1045.

21. D. Eder, Chem. Rev., 2010, 110, 1348-1385. 
22. A. S. Cherevan, P. Gebhardt, C. J. Shearer, M. Matsukawa, K. Domen, and D. Eder, Energy Environ. Sci., 2014, 7, 791-796.

23. S. C. Warren, K. Voïtchovsky, H. Dotan, C. M. Leroy, M. Cornuz, F. Stellacci, C. Hébert, A. Rothschild, and M. Grätzel, Nat. Mater., 2013, 12, 842-849.

24. M. Knez, K. Nielsch, and L. Niinistö, Adv. Mater., 2007, 19, 34253438 .

25. S. Aksel and D. Eder, J. Mater. Chem., 2010, 20, 9149-9145.

26. N. Pinna, J.-F. Hochepied, M. Niederberger, and M. Gregg, Phys. Chem. Chem. Phys., 2009, 11, 3593-3788.

27. S. Deng, S. W. Verbruggen, Z. He, D. J. Cott, P. M. Vereecken, J. A. Martens, S. Bals, S. Lenaerts, and C. Detavernier, RSC Adv., 2014, 4, 11648.

$28 . \quad$ Y.-C. Hsueh, C.-C. Wang, C.-C. Kei, Y.-H. Lin, C. Liu, and T.-P. Perng, J. Catal., 2012, 294, 63-68.

$29 . \quad$ C. Liu, C.-C. Wang, C.-C. Kei, Y.-C. Hsueh, and T.-P. Perng, Small, 2009, 5, 1535-8.

$30 . \quad$ T. Shu, S.-J. Liao, C.-T. Hsieh, A. K. Roy, Y.-Y. Liu, D.-Y. Tzou, and W.-Y. Chen, Electrochim. Acta, 2012, 75, 101-107.

31. J. Dendooven, R. K. Ramachandran, K. Devloo-Casier, G. Rampelberg, M. Filez, H. Poelman, G. B. Marin, E. Fonda, and C. Detavernier, J. Phys. Chem. C, 2013, 117, 20557-20561.

32. S. Haussener, C. Xiang, J. M. Spurgeon, S. Ardo, N. S. Lewis, and A. Z. Weber, Energy Environ. Sci., 2012, 5, 9922-9935.

33. B. Seger and P. V. Kamat, J. Phys. Chem. C, 2009, 113, 1894618952.

34. C. Ampelli, G. Centi, R. Passalacqua, and S. Perathoner, Energy Environ. Sci., 2010, 3, 292-301.

35. J. Rongé, D. Nijs, S. Kerkhofs, K. Masschaele, and J. A. Martens, Phys. Chem. Chem. Phys., 2013, 15, 9315-9325.

36. R. Makharia, M. F. Mathias, and D. R. Baker, J. Electrochem. Soc., 2005, 152, A970-A977.

37. M. Modestino, D. Paul, and S. Dishari, Macromolecules, 2013, 46, 867-873.

38. Z. Siroma, R. Kakitsubo, N. Fujiwara, T. Ioroi, S. Yamazaki, and K. Yasuda, J. Power Sources, 2009, 189, 994-998.

39. W. Han and K. L. Yeung, Chem. Commun., 2011, 47, 8085-7.

40. R. Ravishankar, C. Kirschhock, B. J. Schoeman, P. Vanoppen, P. J. Grobet, S. Storck, W. F. Maier, J. A. Martens, F. C. De Schryver, and P. A. Jacobs, J. Phys. Chem. B, 1998, 5647, 2633-2639.

41. S. D. Tilley, M. Cornuz, K. Sivula, and M. Grätzel, Angew. Chem., 2010, 49, 6549-6552.

42. S. Hu, C. Xiang, S. Haussener, A. D. Berger, and N. S. Lewis, Energy Environ. Sci., 2013, 6, 2984-2993.

43. M. Prévot and K. Sivula, J. Phys. Chem. C, 2013, 117, 1787917893.

44. K. S. Joya, Y. F. Joya, K. Ocakoglu, and R. van de Krol, Angew. Chemie Int. Ed., 2013, 52, 10426-10437.

45. J. Rongé, T. Bosserez, D. Martel, C. Nervi, L. Boarino, F. Taulelle, G. Decher, S. Bordiga, and J. A. Martens, Chem. Soc. Rev., doi: 10.1039/C3CS60424A.

46. J. Rongé, T. Bosserez, L. Huguenin, M. Dumortier, S. Haussener, J. A. Martens, Submitted for publication.

47. H. N. Le Houérou, Bioclimatology and Biogeography of Africa, Springer, 2009.

48. J. M. Spurgeon and N. S. Lewis, Energy Environ. Sci., 2011, 4, 2993-2998.

49. J. A. Turner, Science, 2004, 305, 972-974. 